\title{
Does adoption of inflation targeting reduce exchange rate volatility and enhance economic growth?
}

\author{
Yutaka Kurihara \\ Department of Economics, Aichi University, Nagoya, Japan
}

Email address:

kurihara@vega.aichi-u.ac.jp

\section{To cite this article:}

Yutaka Kurihara. Does Adoption of Inflation Targeting Reduce Exchange Rate Volatility and Enhance Economic Growth? Journal of World Economic Research. Vol. 2, No. 6, 2013, pp. 104-109. doi: 10.11648/j.jwer.20130206.11

\begin{abstract}
Recently, inflation targeting has been adopted in many countries. One important achievement derived from the assessment of this framework can be exchange rate stability, as exchange rate is thought to relate to the target of the inflation rate itself or a stable inflation rate. This article provides empirical analysis of whether or not the adoption of inflation targeting framework has reduced exchange rate volatility. Also, as the final goal of this framework is to attain sound economic growth with a stable and adequate inflation rate, the relationship between inflation targeting and economic growth is examined. The results show that inflation targeting reduces exchange rate volatility and causes economic growth.
\end{abstract}

Keywords: Exchange Rate, Growth, Inflation Targeting, Volatility

\section{Introduction}

Inflation targeting has been adopted in many countries, and the number of countries has been increasing since the beginning of the 1990s. The countries that have adopted this framework are shown in Table 1.

Table 1. Inflation targeting countries

\begin{tabular}{|c|c|c|c|}
\hline Country & $\begin{array}{l}\text { Adoption } \\
\text { Year }\end{array}$ & $\begin{array}{l}\text { Inflation Rate } \\
(\% \text { : end of } 2010)\end{array}$ & $\begin{array}{l}\text { Target } \\
\text { Inflation } \\
\text { Rate }(\%)\end{array}$ \\
\hline New Zealand & 1990 & 4.03 & $1-3$ \\
\hline Canada & 1991 & 2.23 & $2+/-1$ \\
\hline $\begin{array}{l}\text { United } \\
\text { Kingdom }\end{array}$ & 1992 & 3.39 & 2 \\
\hline Australia & 1993 & 2.65 & $2-3$ \\
\hline Sweden & 1993 & 2.65 & $2-3$ \\
\hline $\begin{array}{l}\text { Czech } \\
\text { Republic }\end{array}$ & 1997 & 2.00 & $3+/-1$ \\
\hline Israel & 1997 & 2.62 & $2+/-1$ \\
\hline Poland & 1998 & 3.10 & $2.5+/-1$ \\
\hline Brazil & 1999 & 3.30 & $4.5+/-1$ \\
\hline Chile & 1999 & 2.97 & $3+/-1$ \\
\hline Columbia & 1999 & 3.17 & $2-4$ \\
\hline South Africa & 2000 & 3.50 & $3-6$ \\
\hline Thailand & 2000 & 3.05 & $0.5-3$ \\
\hline Hungary & 2001 & 4.20 & $3+/-1$ \\
\hline
\end{tabular}

\begin{tabular}{llll}
\hline Mexico & 2001 & 4.40 & $3+/-1$ \\
Iceland & 2001 & 2.37 & $2.5+/-1.5$ \\
Korea & 2001 & 3.51 & $3+/-1$ \\
Norway & 2001 & 2.76 & $2.5+/-1$ \\
Peru & 2002 & 2.08 & $2+/-1$ \\
Philippines & 2002 & 3.00 & $4+/-1$ \\
Guatemala & 2005 & 5.39 & $5+/-1$ \\
Indonesia & 2005 & 6.96 & $5+/-1$ \\
Romania & 2005 & 8.00 & $3+/-1$ \\
Serbia & 2006 & 10.29 & $4-8$ \\
Turkey & 2006 & 6.40 & $5.5+/-2$ \\
Armenia & 2006 & 9.35 & $4.5+/-1.5$ \\
Ghana & 2007 & 8.58 & $8.5+/-2$ \\
Albania & 2009 & 3.40 & $3+-1$ \\
\hline
\end{tabular}

Note. From J. Sarwat, "Inflation targeting: Holding the line,” IMF, 2012. (Retrieved from

http://www.imf.org/external/pubs/ft/fandd/basics/target.htm. December 17, 2013).

The pros and cons of adoption of this framework have received much attention since the 1990s. In the past, countries that have experienced high inflation have adopted this framework. Inflation has negative effects on economies in that it reduces savings and investments, promotes capital flights overseas, spurs recession, and, in some cases, causes social and political instability. Generally, countries that 
have adopted an inflation targeting framework have experienced good economic performance [1-7]. Reference [8] noted that countries that the conduct of inflation targeting has resulted in large reductions in both the rate of inflation and inflation expectations beyond the level that would likely have occurred in the absence of an inflation targeting framework. However, it should be noted that the increased focus on inflation stabilization has contributed to reduction of inflation rates from the high rates experienced in the 1970s and 1980s when they were quite high.

Most developed countries and some other economies have suffered deflation starting in the 2000s. To overcome deflation has become the most important problem for some central banks. Japan is a typical case. In April 2013, the Bank of Japan (BOJ) introduced quantitative and qualitative monetary easing. The BOJ decided to achieve the price target of $2 \%$ in terms of the year-on-year rate of change in the consumer price index at the earliest time, with a time horizon of about two years.

In general, inflation targeting is a framework by which central banks publicly set and announce the target rate for inflation; financial policy is then conducted according to this target [9-11]. It has not been long since inflation targeting was first adopted as a framework for financial policy all over the world. The United States has not yet adopted inflation targeting, although the US Congress has considered it in the past. The BOJ recently introduced this practice as mentioned above. The European Central Bank (ECB) does not admit the existence of inflation targeting; however, this framework might be substantially adopted.

Under an inflation targeting framework, central banks have a responsibility to achieve a preannounced goal for the inflation rate. Recently, about 30 central banks all over the world have adopted this framework for the conduct of financial policy (see Table 1), which has proven effective in most cases [10-12]. Many other benefits can be obtained from the adoption of inflation targeting. The success of financial policy under inflation targeting seems to have promoted the introduction of this framework elsewhere.

Many merits may arise from adoption this framework [11]. First, the achievement of the central bank's goal of price stability is difficult to judge without clear standards. With adoption of this framework, market participants can accurately and clearly judge the performance of central banks. Second, clarification of central banks' goals maintains accountability for the target. Finally, this framework confers stability of the expected inflation rate. Stable inflation rate expectations are strongly related to stable inflation rates in markets. Targeting maintains expectations of low inflation, which reduces the inflationary impact of macroeconomic shocks [13].

On the other hand, many negative views of inflation targeting have been presented. First, because control of inflation using other instruments (e.g., monetary base growth or exchange rate) may be less effective [14,15], the credibility of a commitment to inflation targeting may be unstable. So the credibility of the central bank's inflation targeting regarding macroeconomic stabilization is important [16]. Second, if market participants believe the target, there is some possibility of increases in long-run interest rates, for example, which may dampen economic growth. Third, an inflation targeting framework may be achieved at the sacrifice of important economic factors, especially economic growth, for example, in some cases. Fourth, suitable inflation (e.g., CPI or PPI) cannot be decided. Moreover, there are few previous cases in which a central bank introduced inflation targeting to overcome deflation. There is a difference in the introduction of inflation targeting framework between the period of inflation and the period of deflation $[10,11]$.

As mentioned above, most countries' experiences with inflation targeting seem to have been successful. Financial authorities have succeeded in maintaining a stable and moderate rate of inflation while enjoying economic growth. References [17-19] showed that the adoption of an inflation targeting framework has reduced inflation rates and promoted output. An inflation targeting framework appears to be an important instrument for the realization of a stable macroeconomic situation.

Under inflation targeting, the adoption of inflation targeting from other instruments and the emphasis on reduction of inflation has been accompanied by weak economic performance in reality. Many obstacles of inflation targeting frameworks have raised questions regarding their use especially in emerging markets. The difficulty of forecasting inflation has prompted central banks to adopt inflation targeting. It is not realistic to hope to forecast inflation with high reliability if the country is still in the process of reducing inflation from high levels, reforming taxation and public spending, and remaking the banking sector. Many problems associated with serious economic conditions must be overcome and some of them may be too difficult and complicated to solve. Credibility issues related to central banks' problems sometimes make inflation targeting less attractive. These issues may suggest greater volatility and less flexible policy implementation.

Reference [20] showed that inflation in reality would not have differed from the forecasts if the inflation targeting framework had not been adopted. Reference [21] indicated that countries that use an inflation targeting framework with low inflation are at the risk of output losses from increasing inflation.

Some conditions are needed to attain the goal set by inflation targeting frameworks. For example, [22] showed that an inflation targeting framework becomes the optimal policy if prices are flexible or the shock is adequately persistent. Some studies have suggested the impact of fear about the attainment of good performance in domestic macroeconomic variables other than inflation or inflation expectation. For interest rates, [23] showed a positive relationship between expected inflation and interest rates. Also, for fiscal conditions, [24] indicated that a sound fiscal position is positively associated with the decision to implement an inflation targeting framework. 
Moreover, there is a relationship between the degree of openness of the economy and the type of inflation targeting framework [25]. Countries with high openness of the economy tend to be influenced by exchange rates. Changes in import prices caused by movements of the exchange rate are passed quickly to domestic market prices [26]. With this type of high pass-through, a change in the exchange rate has a significant short-run effect on inflation and output. The exchange rate should be adjusted to offset the effects so as not to dampen domestic markets. Reference [27] showed that an increase in exchange rate flexibility is found in inflation targeting countries. Recent deflation in some developed countries also may induce central banks that adopt inflation targeting frameworks to promote depreciation of the domestic currency, whereas an inflationary shock will induce the opposite reaction. Reference [28] indicated that the reactions of financial policy to exchange rate shocks as well as demand/supply shocks have decreased under inflation targeting frameworks.

However, few studies have analyzed the relationship between inflation targeting frameworks and exchange rates. The main reason may be that many emerging countries that have adopted inflation targeting have changed their exchange rate regime from fixed to floating and their financial policy's target from exchange rate to inflation targeting framework only recently. Since the introduction of the floating exchange rate regime, some emerging countries have had to intervene in the foreign exchange markets more than developed economies. Some studies have suggested that foreign exchange market interventions reduce exchange rate volatility, whereas others have found that interventions have a limited effect on volatility. It seems that the results are inconclusive [29].

When the role of the exchange rate under inflation targeting framework is discussed, theoretical and empirical analyses are still mixed [30]. Moreover, few studies have analyzed the relationship between inflation targeting and exchange rate in spite of its importance. Little time has been available to analyze the relationship between inflation targeting and exchange rate.

Reference [31] used generalized impulse response functions and showed that the adoption of an inflation targeting framework decreases the exchange rate pass-through into import, production, and consumer prices. There also is some possibility that the adoption of targeting tends to promote an asymmetrical exchange rate behavior. However, few studies have addressed this topic.

This article is structured as follows. Section 2 provides a theoretical model for the empirical analyses. Section 3 shows empirical analyses to indicate whether or not there is a relationship between inflation targeting and negative exchange rate volatility. Also, the relationships between (1) exchange rate volatility and economic growth and between (2) inflation targeting and economic growth are examined. Finally, a brief summary is provided.

\section{Theoretical Analysis}

Since the 1970s, exchange rates have moved with asset prices. A large amount of capital flows over GDP has occurred over the world. Before that time, exchange rates had moved with international trade volume; however, the situation has changed significantly. This kind of model, called a monetary approach model, relies on a stable money demand function:

$$
M / P=L(Y, i)
$$

where $\mathrm{M}$ denotes the money supply, $\mathrm{P}$ the price level, $\mathrm{L}$ the money demand, Y real income, and i interest rate. A basic assumption of this model is that the supply of money is equal to the demand to hold the money and purchasing power parity (PPP) holds:

$$
S=P / P^{*}
$$

where $\mathrm{S}$ means nominal exchange rate and $\mathrm{P} *$ means foreign price.

Recently, [31] introduced this model, which uses trading goods, and analyzed long-run effects with time-varying coefficients. Many expanded models have been presented; however, this article uses a basic model.

In the $\log$ linearized form, the exchange rate can be expressed as the difference between domestic and foreign money supply, real incomes, and interest rates. If the money supply and income elasticities are equal in each currency market, exchange rates are determined as follows:

$$
s=\alpha+\beta\left(m-m^{*}\right)-\gamma\left(y-y^{*}\right)+c ̧\left(i-i^{*}\right)
$$

where $\alpha$ is a constant term and $\beta, \gamma$, and ç are (semi) elasticities. According to this model, exchange rate is expressed as follows:

$$
s=\left(m-m^{*}, y-y^{*}, i-i^{*}\right)
$$

Some other assumptions underpin this model: (a) real income and money market rate are at equilibrium, (b) domestic and foreign goods are perfect substitutes, (c) uncovered interest rate parity holds, and so on [32-34]. Results from empirical literature reviews also appear mixed. However, this article uses this model for empirical analysis. This model fits well with middle-term analysis (i.e., one year or so).

\section{Empirical Analysis}

This article employs the monetary approach model. The answer depends on the econometric analysis. The estimated equation is as follows.

$$
\begin{aligned}
E X C H A N G E= & a 1+a 2 I N F L A T I O N+a 3 G R O W T H+ \\
& a 4 M O N E Y+a 5 T A R G E T
\end{aligned}
$$

EXCHANGE denotes standard deviation of each month of US-dollar exchange rate. This is changed into a yearly basis. INFLATION is seasonally adjusted and CPI (consumer price index) rate. Inflation and CPI are seasonally 
adjusted. GROWTH means GDP growth rate. MONEY means M1 or other equivalent rates. Interest rate in general causes very fast exchange rate movements, so price is included in the estimation instead. The main reason is the focus on inflation targeting in this article. The adoption of inflation targeting or non-inflation targeting does not change very often. Finally, TARGET indicates whether or not inflation targeting framework is employed. Countries that adopt an inflation targeting framework take one as TARGET and zero otherwise in equation (5).
The estimated countries are shown in Table 2. All of them use an independently floating exchange rate. The left side of the table is countries that used an inflation targeting framework continuously from 2000 to 2012 . The right side of the table, non-inflation-targeting framework, is countries that do not use inflation targeting. It is important to investigate whether structural differences exist between countries that employ inflation targeting and those that pursue other policy frameworks.

Table 2. Estimated countries

\begin{tabular}{|c|c|}
\hline \multicolumn{2}{|c|}{ Countries with Independently Floating Exchange Rates } \\
\hline Inflation Targeting Framework & Non-Inflation Targeting Framework \\
\hline $\begin{array}{l}\text { Australia, Brazil, Canada, Chile, New } \\
\text { Zealand, Poland, South Africa, } \\
\text { Sweden, Thailand, United Kingdom }\end{array}$ & $\begin{array}{l}\text { Afghanistan, Albania, Angola, Armenia, Columbia, Congo, Eretria, Gambia, Georgia, Ghana, Guiana, } \\
\text { Guyana, Haiti, India, Indonesia, Japan, Kazakhstan, Korea, Liberia, Madagascar, Malawi, Mauritius, Mexico, } \\
\text { Moldova, Mongolia, Mozambique, New Guinea, Papua Somalia, Peru, Philippines, Russia, Sierra Leone, } \\
\text { Sudan, Switzerland, Tanzania, Thailand, Uganda, United States, Yemen, Zambia }\end{array}$ \\
\hline
\end{tabular}

Note. Classifications are from International Financial Statistics (IMF).

The empirical method is generalized method of moments (GMM). It is a robust estimator in that, unlike maximum likelihood estimation, GMM does not require information about the exact distribution of the disturbances. Hansen's J statistics test is conducted to check whether or not the model's moment matches the data. In a GMM context, when there are more moment conditions than parameters to be estimated, this chi-square test can be used [33].

The results are shown in Table 3.

Table 3. Empirical results

\begin{tabular}{cccc}
\hline & $\begin{array}{c}\text { Inflation-Targeting } \\
\text { Framework }\end{array}$ & $\begin{array}{c}\text { Non-Inflation } \\
\text { Targeting }\end{array}$ & All \\
\hline C & 0.8782 & 0.1097 & -0.0221 \\
& $(0.0019)$ & $(0.0001)$ & $(-0.2436)$ \\
INFLATION & 13.2359 & -1.5216 & 4.2055 \\
GROWTH & $(0.0238)$ & $(-0.0002)$ & $(0.1412)$ \\
& 1.4382 & -0.3292 & -0.0591 \\
MONEY & $(0.7765)$ & $(-0.0012)$ & $(0.9767)$ \\
& -2.6503 & -0.0151 & -0.0202 \\
TARGET & $(-0.3485)$ & $(0.0000)$ & $(0.0774)$ \\
Adj.R2 & - & - & -0.9935 \\
D. W. & -0.3659 & 0.3040 & $0.0000)$ \\
J-statistic & 1.7778 & 1.9915 & 1.6416 \\
\hline
\end{tabular}

Note. Figures in parentheses in the table are p-values.

The results are quite interesting. Inflation targeting significantly causes exchange rate stability. Namely, stable expectations of exchange rates seem to cause negative exchange rate fluctuations. The results are similar to those in $[35,36]$.

Finally, the relationship between (1) economic growth and inflation targeting framework and (2) economic growth and exchange rate fluctuation are examined. The estimated equations are (6) and (7).

$$
\begin{aligned}
& \text { GROWTH }=b 1+b 2 \text { TARGET } \\
& \text { GROWTH }=c 1+c 2 \text { EXCHANGE }
\end{aligned}
$$

The results are shown in (8) and (9).

$$
\begin{aligned}
\text { GROWTH }= & 0.0407+0.0292 \text { TARGET } \\
& (0.0000)(0.0102)
\end{aligned}
$$

Adj.R2: 0.2996 F-statistic: 8.1273 D.W.: 1.5887

$$
\begin{aligned}
\text { GROWTH }= & 0.0407+0.0046 E X C H A N G E \\
& (0.0001)(0.5397)
\end{aligned}
$$

Adj.R2: 0.2996 F-statistic: 8.1273 D.W.: 1.5887

The result of equation (8) is satisfactory; however, the one for equation (9) is not. The results show that only the adoption of inflation targeting promotes economic growth.

The pairwise Granger causality tests are performed to check the relationship among variables used in this article. The time lag is set at 1 (year). The results are shown in Table 4.

Table 4. Granger causality tests

\begin{tabular}{lll}
\hline & F-statistic & Prob. \\
\hline TARGET does not cause GROWTH & 0.0022 & 0.9125 \\
GROWTH does not cause TARGET & 0.4962 & 0.4885 \\
& & \\
EXCHANGE does not cause GROWTH & 0.0275 & 0.8698 \\
GROWTH does not cause EXCHANGE & 1.1171 & 0.3020 \\
& & \\
EXCHANGE does not cause TARGET & 0.0097 & 0.9224 \\
TARGET does not cause EXCHANGE & 7.7392 & 0.0109 \\
\hline
\end{tabular}

The results show strongly that inflation targeting causes economic growth; however, exchange rate stability does not necessarily cause economic growth. 


\section{Conclusion}

This article examined empirically whether or not the adoption of inflation targeting reduces exchange rate fluctuation and induces economic growth. The results show that inflation targeting is an effective way to promote economic growth. However, there is some room for further study. Little time has passed since the adoption of the inflation targeting framework in many countries, so the sample size is small. Also, the economic situation in each country is quite different. The incentives to adopt inflation targeting are significantly different in economics [37]. To judge whether or not inflation targeting has been successful has many limitations that may impact adequate analysis. This is a main reason why this article focused on the relationship between exchange rate fluctuation and inflation targeting rather than depend on the direct analysis between inflation targeting and prices [38-40].

Of course, the financial policy outcomes under the adoption of inflation targeting may reflect improved broader economic, not only financial, policy-making. This paper indicates that exchange rate stability under an inflation targeting framework does not play a significant role in stabilizing inflation; however, inflation targeting causes exchange rate stability. In some countries, policymakers must debate the appropriate role of the exchange rate and whether it should be subordinate to inflation targeting. This is one of the important issues for policymakers in developing countries. Inflation is affected by many factors both from abroad and domestically. Countries that are affected by external factors may not see any merit in the adoption of inflation targeting. Also, if the real exchange rate depreciates and the economy becomes more open, the exchange rate depreciation as an effect of rising import prices becomes more harmful. In such a case, financial authorities have a disincentive to allow inflation. For them, it would be better if the inflation rate keeps more flexible. Making the rate of inflation flexible allows their exchange rate to change in a desirable direction. However, when the inflation rate is high, it is unclear whether or not this case is applicable. Further and deep analysis of every aspect is needed in the future.

\section{Acknowledgements}

I thank an anonymous referee for valuable comments and suggestions. Publication of this article was supported by a grant-in-aid from Zengin Foundation for Studies on Economics.

\section{References}

[1] Mishkin, F. S. and Posen, A. S. (1998). Inflation targeting: Lessons from four economics, NBER Working Paper, 6126.

[2] Henrik, J. (2002). Targeting nominal income growth or inflation, The American Economic Review, 92(4), 928-956.
[3] Roger, S. and Stone, M. (2005). On target? The international experience with achieving inflation targets, IMF Working Paper, wp/05/163.

[4] Sikos, P. L. (2008). Emerging markets finance and trade, 44(6), 17-37.

[5] Roger, S. (2009). Inflation targeting at 20: Achievements and challenges, IMF Working Paper, wp/09/236.

[6] Onur, T. (2012). Inflation targeting and inflation uncertainty, Scottish Journal of Political Economy, 59(3), 283-297.

[7] Woodford, M. (2009). Inflation targeting and financial stability, NBER Working Paper, 17967.

[8] Mishkin, F. (2001). Inflation targeting in emerging market countries. NBER Working Paper, 7618.

[9] Fountas, S., Karanasos, M. and Kim, J. (2002). Inflation and output growth uncertainty and their relationship with inflation and output growth. Economics Letters, 75(2), 293-301.

[10] Kurihara, Y. (2003). Why do EU countries use inflation targeting? Global Business and Economics Review, 7(1), $74-84$.

[11] Kurihara, Y. (2010). Has inflation targeting been effective? International Journal of Business, 15(4), 411-422.

[12] Svensson, L.E.O. and Woodford, M. (2005). Implementing optimal policy through inflation-forecast targeting, in S. Bernanke and M. Woodford, The Inflation-Targeting Debate, Chicago: The University of Chicago Press.

[13] Svensson, L.E.O. (1997). Inflation forecast targeting: implementing and monitoring inflation targets. European Economic Review, 41(6), 1111-1146.

[14] Ceccetti, S. G. and Ehrmann, M. (1999). Does inflation targeting increase output volatility? An international comparison of policymaker's preferences and outcomes, NBER Working Paper, 7426.

[15] Gonçalves, C. E. S. and salles, J. M. (2008). Inflation targeting in emerging economies: What do the data say, Journal of Development Economics, 85(1/2), 312-318.

[16] Salle, I., Yidizoglu, M. and Sénégas, M. (2013). Inflation targeting in a learning economy: An ABM perspective, Economic Modelling, 34, 114-128.

[17] Chu, J. F. and Sek, S. K. (2012). Evaluating the performance of inflation targeting, International Journal of Economics and Finance, 4(9), 69-86.

[18] De Mendonça, H. F. and Souza, G. J. (2010). Is inflation targeting a good remedy to control inflation? Journal of Development Economics, 98(2), 178-191.

[19] Gerlach, S. and Tillmann, P. (2012). Inflation targeting and inflation persistence in Asia-pacific, Journal of Asian Economics, 23(4), 360-373.

[20] Geno, I. H. and Balcilar, M. (2012). Effectiveness of inflation targeting in Turkey, Emerging Markets, Finance \& Trade, 48(1), 35-47.

[21] Hartmann, M. and Roestel, J. (2013). Inflation, output and uncertainty in the era of inflation targeting - A multi-economy view on causal linkage, Journal of International Money and Finance, 37, 98-112. 
[22] Arslam, M. M. (2013). Optimal monetary policy with the sticky information model of price adjustment: Inflation or price level targeting? Bulletin of Economics Research, Supplement s1, 65, s106-s129.

[23] Mallik, G. and Bhar, R. (2011). Has the link between inflation uncertainty and interest rates changed after inflation targeting? Journal of Economic Studies, 38(6), 620-636.

[24] Hu. Y. (2005). The choice of inflation targeting - An empirical investigation, International Economics and Economic Policy, 3(1), 27-42.

[25] Bousrih, J. (2012). Degree of openness and inflation targeting policy: Model of a small open economy, Journal of Financial Economic Policy, 4(3), 232-246.

[26] Calvo, G. and Reinhart, C. (2000). Fear of floating. NBER Working Paper, 7993.

[27] Ghosh, A. (2013). Exchange rate flexibility in Latin America, Journal of Financial Economic Policy, 5(2), 238-250.

[28] Sek, S. K. (2008). Interactions between Monetary Policy and Exchange Rate in Inflation Targeting Emerging Countries: The Case of Three East Asian Countries, International Journal of Economics and Finance, 1(2), 27-44.

[29] Petreski, M. (2012). Output volatilities and exchange rate considerations under inflation targeting: A review, International Journal of Economics and Financial Issues, 2(4), 528-537.

[30] Odrïa, L., Castillo, P. and Rodriguez, G. (2013). Does the exchange rate pass-through into prices change when inflation targeting is adopted? The Peruvian case study between 1994 and 2007, Journal of Macroeconomics, 34(4), 1154-.

[31] Beckmann, J., Belke, A. and Kuhl, M. (2011). The dollar-euro exchange rate and macroeconomic fundamentals: A time-varying coefficient approach, Review of World Economics, 147, 11-40.

[32] De Grauwe, P. and Vansteenkiste, I. (2007). Exchange rate and fundamentals: A non-linear relationship? International Journal of Finance and Economics, 12(1), 37-54.

[33] Kurihara, Y. (2012). Exchange Rate Determination and Structural Changes in Monetary Policy, Studies in Economics and Finance, 29(3), 187-196.

[34] Sarno, L., Valente, G. and Wohar, M. E. (2004). Monetary fundamentals and exchange rate dynamics under different nominal regimes, Economic Inquiry, 42(2), 179-193.

[35] Edwards, S. (2006). The relationship between exchange rate and inflation targeting revisited, NBER Working Paper, 12163.

[36] Aizenman, J. and Hutchism, M. (2011). Inflation targeting and real exchange rates in emerging markets, 39(5), 712-724.

[37] Wei, D. (2013). Do central banks respond to exchange rate movement? Some new evidence from structural estimation, The Canadian Journal of Economics, 46(2), 555-.

[38] Clarida R., Gali, J. and Gertler, M. (1998). Monetary policy rule in practice: Some international evidence. European Economic Review, 46(1), 1033-1068.

[39] Pontines, V. and Siregar, R. Y. (2012). Exchange rate asymmetry and flexible exchange rates under inflation targeting regimes: Evidence from four East Southeast Asian countries, Review of International Economics, 20(5), 893-908.

[40] Willard, L. B. (2012). Does inflation targeting matter? A reassessment, Applied Economics, 44(17), 2231-2244. 